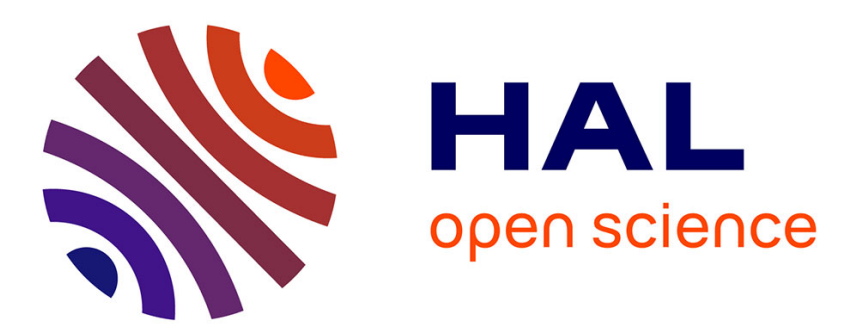

\title{
And yet it shrinks: a novel method for correcting bias in forest tree growth estimates caused by water-induced fluctuations
}

Rutuja Chitra-Tarak, Laurent Ruiz, Sandeep Pulla, H. S. Dattaraja, H. S. Suresh, Raman Sukumar

\section{To cite this version:}

Rutuja Chitra-Tarak, Laurent Ruiz, Sandeep Pulla, H. S. Dattaraja, H. S. Suresh, et al.. And yet it shrinks: a novel method for correcting bias in forest tree growth estimates caused by water-induced fluctuations. Forest Ecology and Management, 2015, 336, pp.129-136. 10.1016/j.foreco.2014.10.007 . hal-01209269

\section{HAL Id: hal-01209269 \\ https://hal.science/hal-01209269}

Submitted on 27 May 2020

HAL is a multi-disciplinary open access archive for the deposit and dissemination of scientific research documents, whether they are published or not. The documents may come from teaching and research institutions in France or abroad, or from public or private research centers.
L'archive ouverte pluridisciplinaire HAL, est destinée au dépôt et à la diffusion de documents scientifiques de niveau recherche, publiés ou non, émanant des établissements d'enseignement et de recherche français ou étrangers, des laboratoires publics ou privés. 


\title{
And yet it shrinks: A novel method for correcting bias in forest tree growth estimates caused by water-induced fluctuations
}

\author{
Rutuja Chitra-Tarak ${ }^{\mathrm{a}, 1}$, Laurent Ruiz ${ }^{\text {b,c }}$, Sandeep Pulla ${ }^{\mathrm{a}}$, H.S. Dattaraja ${ }^{\mathrm{a}}$, H.S. Suresh ${ }^{\text {a }}$ \\ Raman Sukumar ${ }^{\mathrm{a}, \mathrm{d}, *}$ \\ ${ }^{a}$ Centre for Ecological Sciences, Indian Institute of Science, Bangalore 560012, India \\ b INRA, Agrocampus Ouest, UMR1069, Sol Agro et hydrosystème Spatialisation, 35000 Rennes, France \\ ${ }^{\mathrm{C}}$ Indo-French Cell for Water Sciences, IISc-IRD Joint Laboratory, Indian Institute of Science, Bangalore 560012, India \\ ${ }^{\mathrm{d}}$ Divecha Centre for Climate Change, Indian Institute of Science, Bangalore 560012, India
}

\section{A R T I C L E I N F O}

\section{Article history:}

Received 25 July 2014

Received in revised form 25 September 2014

Accepted 1 October 2014

Available online 9 November 2014

\section{Keywords:}

Reversible stem flexing

Tree shrinkage

Seasonally dry tropical forest

Above-ground biomass

Carbon

Permanent sampling plot

\begin{abstract}
A B S T R A C T
Accuracy in tree woody growth estimates is important to global carbon budget estimation and climatechange science. Tree growth in permanent sampling plots (PSPs) is commonly estimated by measuring stem diameter changes, but this method is susceptible to bias resulting from water-induced reversible stem shrinkage. In the absence of bias correction, temporal variability in growth is likely to be overestimated and incorrectly attributed to fluctuations in resource availability, especially in forests with high seasonal and inter-annual variability in water. We propose and test a novel approach for estimating and correcting this bias at the community level.

In a 50-ha PSP from a seasonally dry tropical forest in southern India, where tape measurements have been taken every four years from 1988 to 2012, for nine trees we estimated bias due to reversible stem shrinkage as the difference between woody growth measured using tree rings and that estimated from tape. We tested if the bias estimated from these trees could be used as a proxy to correct bias in tapebased growth estimates at the PSP scale.

We observed significant shrinkage-related bias in the growth estimates of the nine trees in some censuses. This bias was strongly linearly related to tape-based growth estimates at the level of the PSP, and could be used as a proxy. After bias was corrected, the temporal variance in growth rates of the PSP decreased, while the effect of exceptionally dry or wet periods was retained, indicating that at least a part of the temporal variability arose from reversible shrinkage-related bias. We also suggest that the efficacy of the bias correction could be improved by measuring the proxy on trees that belong to different size classes and census timing, but not necessarily to different species.

Our approach allows for reanalysis - and possible reinterpretation - of temporal trends in tree growth, above ground biomass change, or carbon fluxes in forests, and their relationships with resource availability in the context of climate change.
\end{abstract}

(c) 2014 Elsevier B.V. All rights reserved.

\section{Introduction}

Accuracy in tree woody growth estimates is critical to global carbon budget estimation and climate-change science (Clark and Kellner, 2012; Malhi, 2012). The most commonly and widely used

\footnotetext{
* Corresponding author at: Centre for Ecological Sciences, Indian Institute of Science, Bangalore 560012, India. Tel.: +91 8023600382 (Direct), +91 8022933102 (Office); Fax: +91 8023602280.

E-mail addresses: arutuj@gmail.com(R.Chitra-Tarak),ruiz@rennes.inra.fr(L. Ruiz), sandeep@ces.iisc.ernet.in (S. Pulla), dattaraj@ces.iisc.ernet.in (H.S. Dattaraja), suresh@ces.iisc.ernet.in (H.S. Suresh),rsuku@ces.iisc.ernet.in (R. Sukumar).

${ }^{1}$ Co-corresponding author. Tel.: +919483190581.
}

method for estimating tree growth in permanent sampling plots (PSPs) involves the measurement of successive stem diameter changes using a graduated tape or a dendrometer band, and is followed by the use of allometric equations (Chave et al., 2014, 2005) to estimate the above-ground biomass (AGB) or carbon of the plot and changes therein (Condit, 1998; Marthews et al., 2012). However, potentially biases and uncertainties in the measurements in PSPs can substantially affect estimates of forest tree growth, and thus AGB and carbon pools and fluxes (Cushman et al., 2014; Muller-Landau et al., 2014; Sheil, 1995; Talbot et al., 2014).

Water-induced expansion and shrinkage of tree trunks poses a major challenge in the accurate measurement of woody diameter change (Sheil, 2003, 1997). This is because diameter change as 
measured by a tape or a dendrometer band not only arises from irreversible woody growth (cell wall extension and cell division), but also from reversible expansion and shrinkage in the stem due to water-induced fluctuations. Bias in woody growth estimates due to this reversible stem flexing occurs if the water status of the tree is different across successive measurements (Baker et al., 2002; Sheil, 1995). In the absence of bias correction, temporal variability in growth rates is likely to be overestimated and wrongly attributed to fluctuations in resource (e.g. water) availability. To our knowledge, such biases have not been satisfactorily estimated so far, as no study has measured and separated actual woody growth from water-induced fluctuations at the level of forest community, and no satisfactory method of correcting this bias at this scale is currently available.

Diameter change due to reversible stem flexing occurs as the stem tissues storing water reversibly constrict due to dehydration. This is induced by reduced xylem water potential (Worrall, 1966, Kozlowski, 1990), which is determined by transpiration demand and below-ground water availability. Depending on the species, the largest fraction of the reversible stem flexing is known to occur in the bark (Zweifel and Häsler, 2001) or in the outer parenchyma the tissues in between the cambium and the cork (Scholz et al., 2008). A water potential difference between xylem and bark causes a radial flow of water from the stem storage compartment towards the xylem, causing the stem bark diameter and consequently the stem diameter, to shrink. The xylem contributes much less to the reversible flexing, although it likely stores and supplies water for about $10-50 \%$ of daily transpiration demand (Holbrook and Zwieniecki, 2011).

Much variation in reversible stem flexing occurs with respect to species and in time due to variations in environmental factors affecting water stress, as reviewed by Baker et al. (2002). Temporal variation occurs at a diurnal scale as tree stems typically contract during the day when leaves transpire, and rehydrate during the night (Karling, 1934; Klepper et al., 1971). At a seasonal scale, stem shrinkage during the dry season occurs due to high transpiration demands and depletion of the soil water reserve. Species differ in the extent and timing of reversible stem flexing (Kozlowski and Winget, 1964; Scholz et al., 2008). This is possibly due to differences in timing of leaf flush, flowering or fruiting (Baker et al., 2002), and differences in tissue structures, and/or in relative proportions of various tissues - causing differences in water storage capacity and/or volume change per unit change in water content (Scholz et al., 2008). In the absence of leaves, water stored in the trunk may last across seasons, enabling rehydration of stem tissues and subsequent flowering or flushing (Borchert, 1994a, 1994b; Holbrook and Zwieniecki, 2011). The extent and timing of shrinkage within a species can differ according to topographic position and rooting depth, which influences access to water (Borchert, 1994b; Markesteijn et al., 2010; Meinzer et al., 1999). The effect of tree size on the direction and extent of reversible flexing is debated (Baker et al., 2002). In summary, diameter change in stems can arise not only from woody growth, but also from water-induced reversible flexing, which we hereafter refer to as "water growth".

The case that biases in growth estimates of PSPs could arise from short term - diurnal and seasonal - water-induced fluctuations was first made by Sheil (1997). Negative tree growth estimates are commonly reported in dry forests, which are attributed to water growth and are considered biases (Sheil, 1995). Reversible stem flexing has long since known to be substantial compared to irreversible woody growth and thermal changes (Kozlowski, 1971). The extent of seasonal shrinkage varies from year to year (Baker et al., 2002; Pélissier and Pascal, 2000), and is likely to lead to substantial biases in growth estimates based on annual or supra-annual censuses (Baker et al., 2002; Pélissier and Pascal, 2000). We expect that the largest biases in growth are likely in forests where both high seasonal and inter-annual variability in water is observed, as often found in seasonally dry tropical forests (SDTFs) (Maas and Burgos, 2011).

A few studies have tried to use a measure of short-term water availability such as rainfall or soil moisture and transpiration demand to account for water growth. Sheil (1997) observed that growth rates of most stems in an Ugandan semi-deciduous forest showed an apparent reduction when measured over wetter seasonal periods, presumably due to measurements during the wetter season being typically made on drier, bright, sunny days when trees are in full leaf and diurnal shrinkage is high. Soil water potential at the time of measurement explained the bias in annual growth estimates in a two year study in a semi-deciduous forest in Ghana (Baker et al., 2002).

Prescriptions for the optimal timing of annual diameter measurements to minimize bias due to diurnal and seasonal water growth have been controversial for seasonally dry forests. For example, Pélissier and Pascal (2000) suggested that inter-annual variation in dry season shrinkage might be stronger than wet season expansion, and therefore recommended measuring growth in the wet season in order to minimize bias in annual growth measurements. Baker et al. (2002) observed greater inter-annual variability in diameter change during the dry season, and also prescribed the wet season for measuring annual growth. However, Sheil (2003) claimed that observations by Baker et al. (2002) of higher variability in diameter change in dry season was debatable, given measurement errors of dendrometer bands and exceptional drought conditions in that study. Sheil (2003) suggested that "wet season measures are more perturbed by moisture (deficits and availability) and by phenological events (flowers, fruit, etc.) impacting true growth. Dry season quiescence reduces growth variance".

However, these hypotheses have remained untested in the absence of actual measurements of the two components of diameter change - woody growth and water growth. Tree ring widths can provide a measure of actual woody growth at annual scale. However this method is invasive, and also expensive in terms of required expertise and resources. Thus estimating bias at the community level needs other approaches.

In this study we propose a novel approach for estimating and correcting bias in growth estimates due to water-induced fluctuations at the community level. We used long-term diameter census data from a PSP in a southern Indian seasonally dry tropical forest. Comparing woody growth using tree rings and observed growth using a tape in a small number of trees, we check whether significant biases in tree growth estimates were due to water growth. We then test whether biases in this small number of trees can be used as a proxy to correct biases in tree growth at the community level. We also suggest ways to improve this approach.

\section{Materials and methods}

\subsection{Study site, climate and forest plot}

We used data from a 50-ha Mudumalai Forest Dynamics Plot (MFDP) located in a seasonally dry tropical forest in the Western Ghats, southern India (Latitude: 11.5989, Longitude: 76.5338). Detailed information on this forest and the 50-ha plot can be found elsewhere (Sukumar et al., 1998, 1992; Suresh et al., 2013, 2010). The average annual precipitation $4 \mathrm{~km}$ from the site is 1200 ( \pm 280 SD) mm from 1988 to 2013 (Fig. 1).

About $80 \%$ of annual precipitation occurs during the monsoon from June to November. The dry period $(<100 \mathrm{~mm}$ precipitation/ month) lasts for about 6-8 months, with four months of less than $50 \mathrm{~mm}$ precipitation/month from December to March. Average monthly maximum and minimum temperatures are $27.4^{\circ} \mathrm{C}( \pm 2.7$ 


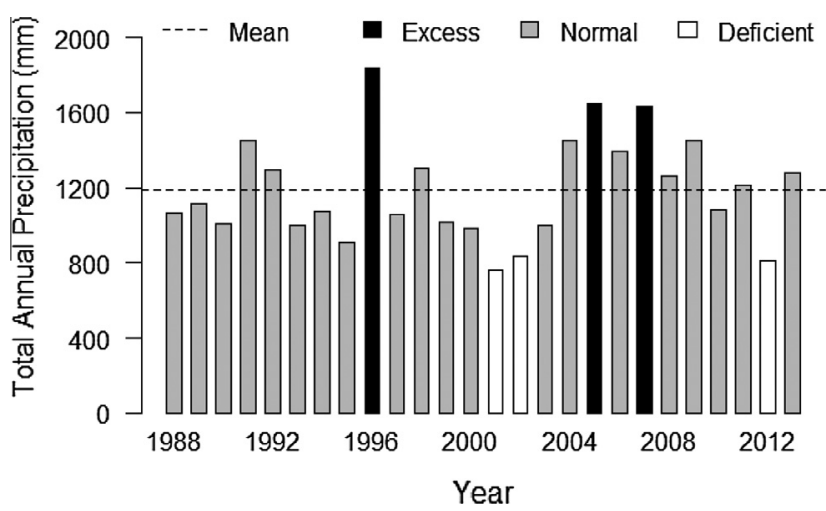

Fig. 1. Total annual precipitation at Kargudi, $3 \mathrm{~km}$ away from the 50 ha MFDP. Data for the year 1988 and 1989 has been derived from a regression between Kargudi and Gamehut rainguage records (Nath et al., 2006). Mean Annual Precipitation (MAP) during the study period, from 1988 to 2013, is shown with a dotted line. Years with excess $(>120 \%$ MAP) and deficient $(<70 \%$ MAP) precipitation are highlighted. The study period ended in March 2013. Precipitation during January to March 2013 was $23.6 \mathrm{~mm}$

SD) and $16.4^{\circ} \mathrm{C}( \pm 2.0 \mathrm{SD})$ respectively. The forest type is classified as tropical dry deciduous by Champion and Seth (1968) and Puri (1960). Most trees are deciduous from January to March (Murali and Sukumar, 1993; Prasad and Hegde, 1986; Suresh and Sukumar, 2009).

\subsection{Tape-based growth censuses for the 50-ha MFDP}

In the 50-ha plot all woody plant stems $>10 \mathrm{~mm}$ have been censused for diameter at breast height $(1.3 \mathrm{~m}$, DBH) every four years, from 1988 to 2012 (Table 1). These stems are mapped, tagged with a unique number, identified to species (or morphospecies), measured for DBH with a graduated tape/caliper (1-mm resolution) following the Centre for Tropical Forest Science protocols (Condit et al., 1999). Each census typically began in June and took about 6-9 months to complete (Table 1), maintaining the same sequence of enumeration - from 1 st to 50 th hectare from the south-west to north-east end of the $0.5 \mathrm{~km} \times 1 \mathrm{~km}$ plot. However, the first census in 1988 continued for one full year, whereas census in 1996, which followed a fire earlier that dry season, was completed within 3 months. DBH measurements were typically carried out between $9 \mathrm{am}$ and $2 \mathrm{pm}$, in effect restricting diurnal variation in $\mathrm{DBH}$, for we observed maximum shrinkage during late afternoons (unpublished results).

In this study, we only used trees that were present in all censuses in order to avoid bias due to the turnover of individuals and species and due to large changes in the size-class distribution. Further, we chose only trees with single stems in order to avoid bias due to swapping of diameter measurements of multiple stems (individual stems were not tagged). This subsample will be referred to as the "community-level" set hereafter. Diameter change (in $\mathrm{cm}$ ) during each census interval was annualized by dividing with inter-census period, i.e. four years. We identified "spike" growth values in each tree's record that lay outside the mean $\pm 3 *$ standard deviation range based on the remaining growth values in its census history, and whose absolute value was greater than $1 \mathrm{~cm} \mathrm{yr}^{-1}$. We also considered growth rates with magnitudes greater than $4 \mathrm{~cm} \mathrm{yr}^{-1}$ as unrealistic or erroneous. In both cases we removed the corresponding trees from the dataset in order to retain a fixed set of trees across all censuses. The "communitylevel" set contained 9016 trees.

\subsection{Measuring woody growth using tree rings in a sample of trees}

For measuring woody growth, we selected nine seemingly healthy and straight-boled trees from the MFDP in the 30-60 cm DBH size class belonging to three species - Tectona grandis $\mathrm{L}$. $\mathrm{f}$. ( $n=$ five), Terminalia crenulata Roth. $(n=$ three), and Lagerstroemia microcarpa Wt. ( $n=$ one) that show distinguishable annual rings and rank among the top four dominant canopy species in the plot (Sukumar et al., 2004). These nine trees were located within $80 \mathrm{~m}$ of each other in the north-east end of the MFDP and thus have been consistently measured in the last phase of each census, typically, during or after December (Table 1). As a consequence, barring the 1996 census when measurements were taken in September, in all other censuses these trees were measured mostly in their deciduous stages. This ensured that annual growth in the census year was complete. For the 1996 census, a fraction of woody growth is likely to have occurred after the census measurement in mid-late September, but only until leaf fall in December as, for example, it is known that in Tectona grandis the cambium is dormant during the leafless period (Rao and Dave, 1981). However not more than $1 / 5$ th of annual growth is likely to have occurred during this period given that the leafy period is from April to December, and the period with mature leaves extends from July to December.

For each tree, cores of about $100 \mathrm{~mm}$ long and $5 \mathrm{~mm}$ in diameter were taken in three to five radial directions at the height of $125 \mathrm{~cm}$ from the tree base. The openings left on the trees due to the coring were then sealed with wax. After polishing the cores, rings were dated and their widths measured with an increment measuring machine coupled with a stereo-zoom microscope (0.01 $\mathrm{mm}$ accuracy). For each tree, yearly ring widths from three to five collected cores were pooled together and twice the average of these widths was taken to represent woody growth in diameter for the given year. For each tree, the mean annual woody growth during each census interval was calculated by taking the average of woody growth in diameter for all the growth years during the census interval, as detailed in Table 1.

\subsection{Data analyses: measuring bias in tape-based growth estimates in the cored trees}

For this analysis we assumed that the difference between tapemeasured and ring-measured diameter change was due to waterinduced fluctuations, although some part of the difference could also originate from other sources such as bark addition/removal/ injury, and measurement errors. We write:

Table 1

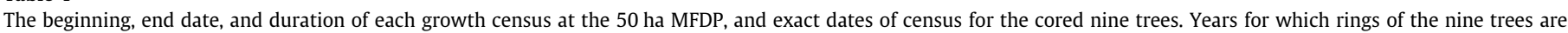
included to calculate ring growth for each census-interval are given.

\begin{tabular}{|c|c|c|c|c|c|}
\hline Census & Enumeration start date & Enumeration end date & Census duration (months) & Census dates for the selected 9 trees & Rings included in the interval \\
\hline 1988 & 19 May 1988 & 12 May 1989 & 12 & 02, 04, 12 May 1989 & \\
\hline 1992 & 09 June 1992 & 02 December 1992 & 6 & 19, 20 November, 21 December 1992 & 1989-1992 \\
\hline 1996 & 25 June 1996 & 21 September 1996 & 3 & 14, 15, 21 September 1996 & $1993-1996$ \\
\hline 2000 & 01 August 2000 & 19 December 2000 & 5 & 14, 15, 19 December 2000 & $1997-2000$ \\
\hline 2004 & 08 August 2004 & 02 December 2004 & 5 & 30 November, 02 December 2004 & 2001-2004 \\
\hline 2008 & 09 June 2008 & 07 March 2009 & 9 & 19, 20, 21 February, 07 March 2009 & $2005-2008$ \\
\hline 2012 & 15 June 2012 & 09 March 2013 & 9 & 25, 27 February, 07 March 2013 & 2009-2012 \\
\hline
\end{tabular}


Tape-measured diameter change $=$ water-induced diameter change + ring-measured diameter change

For simplicity, we refer to the above terms as:

Tape growth $=$ Water growth + Ring growth

To examine whether or not water growth explains tape growth or ring growth, we performed linear regressions between these variables, tested the significance of the slope and intercept, and examined the proportion of explained variance. We also examined whether or not mean water growth was significantly different from zero across censuses and for each census separately, using the Student's $t$-test.

\subsection{Data analyses: estimating and correcting bias in tape growth at} the community-level using bias in the cored trees as a proxy

We first tested if census-interval-wise mean tape growth for the "community-level" tree set had a significant linear relationship with census-interval wise mean water growth for the nine trees ( $n=6$ census intervals), specifically by verifying whether or not the slope of the linear regression was significantly different from zero. Since the slope was significant (see Results Section 3.2), we subtracted slope effect of the water growth from the corresponding tape growth value for each tree in the community level set to obtain an estimate of woody growth.

\subsection{Data analyses: examining effect of measurement time, diameter} and species of the cored trees in estimating bias in community-level tape growth

We prepared three subsets of the "community-level" tree set in order to examine the effect of the choice of cored trees - with respect to measurement time, tree diameter and species identity - on the effectiveness of bias correction. The "community-level" censuses had been carried out over six to nine months, and thus were likely to include large variations in tree water status over time, compared to the nine trees selected for coring. The first subset therefore only included trees that were censused within \pm 1 month of the census dates of the nine trees (Table 1 ). This set of trees is likely to have undergone similar changes in water status as the nine cored trees, and is hereafter referred to as the "censusduration restricted" set ( $n=1535$ trees), The second subset only included trees from the "community-level" set that were in the same size class ( $>20 \mathrm{~cm} \mathrm{DBH}, n=5841$ ) as the cored set. This was called the "large" tree set (for reference, the remaining trees (i.e. $1-20 \mathrm{~cm}$ DBH) were called the "small" tree set). The third subset only included trees from the "community-level" set that belonged to the species as the cored set. This was called the "selected-species" set ( $n=5715$ trees). For each of these three subsets, we fitted linear regressions between the census-interval wise mean water growth of the cored trees and census-interval wise mean tape growth of the set. We expected the slopes of these linear regressions to be higher than the slope of the regression for the full "community-level" set.

All analyses were done in $\mathrm{R}$ statistical environment, version 3.0.2 (R Core Team, 2013).

\section{Results}

\subsection{Bias in growth estimates in the cored trees}

For the nine cored trees, all six census-intervals together, variability in water growth was about double that in ring growth, but similar to that in tape growth (Fig. 2a). Water growth was not related to ring growth (Fig. 2b, Table 2). Tape growth was found to be a poor predictor of ring growth (Fig. 2c, Table 2). Water growth, however, showed a significant linear relationship with tape growth and also explained large proportion of the variance therein (Fig. 2d, Table 2). This suggests that most of the variability in tape growth arose from water-induced fluctuations and measurement errors. All six census-intervals together mean water growth was not significantly different from zero. This indicates that all censuses together, mean tape growth was not a biased estimator of ring growth.

Census-interval wise (Fig. 3a), both tape and ring growth displayed significant variations in some years, but contrasting temporal patterns. However, mean water growth was significantly different from zero only for the first two census intervals, and not the last four (Fig. 3b). The variance in water growth remained high in each of the censuses.

3.2. Estimating and correcting bias in tape growth at the communitylevel using bias in the cored trees as a proxy

Mean water growth of the nine trees in each census had a significant linear relationship with census-interval wise tape growth of the "community-level" tree set (Fig. 4), suggesting that water growth even measured for a few trees can be used as a proxy for bias in growth estimates of trees at the "community-level" that are censused over six to nine months.

Before bias correction, mean tape growth across census-intervals was $0.247 \mathrm{~cm} \mathrm{yr}^{-1}$ with a standard deviation of $0.47 \mathrm{~cm} \mathrm{yr}^{-1}$ (Fig. 5a). Mean growth for census interval 1988-1992 and 19962000 was higher than the mean growth for 2004-2008, and mean growth for 2000-2004 was lowest, while that for 1992-1996 was lowest. After bias correction, mean growth across censuses was $0.237 \mathrm{~cm} \mathrm{yr}^{-1}$, with a standard deviation of $0.23 \mathrm{~cm} \mathrm{yr}^{-1}$. Thus the coefficient of variation in census-interval wise mean growth reduced by $50 \%$ (Fig. 5b: from 0.190 to 0.097 ) and that for median by about $20 \%$ (from 0.167 to 0.137 ).

After bias correction, the 2004-2008 census-interval emerged as the one with the highest mean growth, while census-interval 2000-2004 remained as the one with the lowest mean growth, and emerged as the only interval with significantly lower growth than the mean growth across intervals (Fig. 5b). Mean growth for census-interval 1988-1992 and 1992-1996 emerged close to the mean growth across census-intervals. Bias correction had a much stronger effect on mean/median tape growth for the first three censuses than for the last three. This was expected because mean water growth in the nine cored trees in the last three censuses was close to zero, but highly positive or negative in the earlier censuses (Fig. 3b).

\subsection{Examining effect of measurement time, diameter and species of} the cored trees in estimating bias in community-level tape growth

As in the case of "community-level" tree set, for all the other subsets defined earlier, namely, "census-duration restricted", "selected-species", "large" and "small" tree sets, we found a significant linear relationship between census-interval wise tape growth for trees in each of these groups and the proxy for bias, that is, the census-interval wise mean water growth in the nine trees. The slope of this linear relationship for the "census-duration restricted" and "large" tree set was significantly higher than the slope for the "community-level" tree set, but not for the "selected-species" tree set. The slope for the "large" tree set was also significantly higher than that for the "small" tree set (Fig. 6). This suggested that water growth measured based on the nine cored trees as a proxy was more efficient in reducing bias in growth estimates of trees 

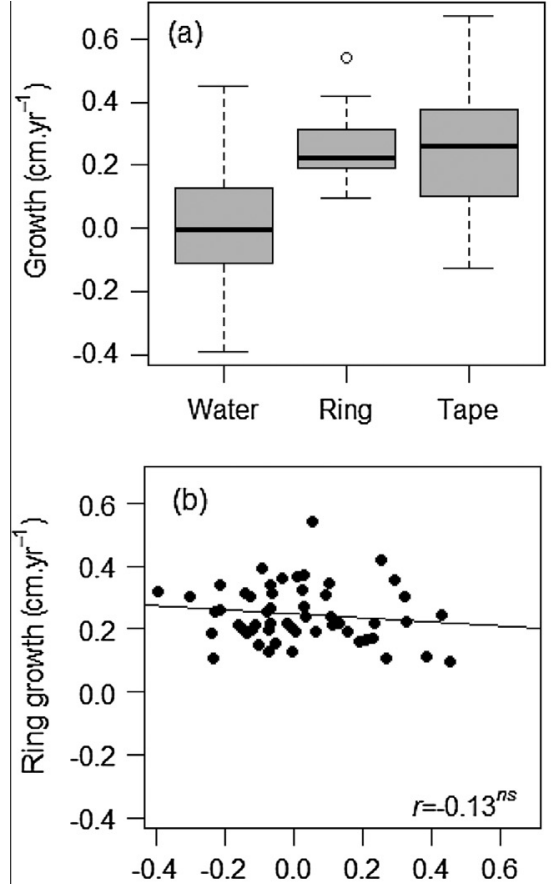

Water growth $\left(\mathrm{cm}_{\mathrm{yr}} \mathrm{yr}^{-1}\right)$
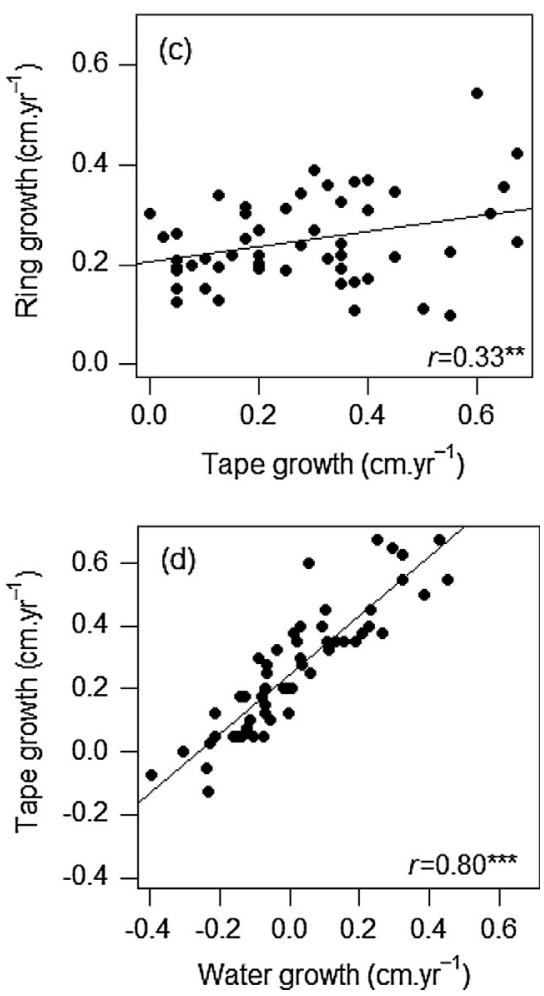

Fig. 2. Comparison between tape, ring and water growth in the nine cored trees, all six census intervals pooled together $(9 \times 6=54$ data points). (a) Distribution of tape, ring and water growth. The median (black line), interquartile range (IQR) (upper and lower limits of the boxes; 75 and 25 percentile), and variation extending to 1.5 times the IQR (whiskers) are given. Associations between (b) ring and water, (c) ring and tape, and (d) tape and water growth. Regression line and Pearson correlation coefficients with their level of significance are given. $n s$, non-significant: ${ }^{*} P \leqslant 0.05,{ }^{* *} P \leqslant 0.01,{ }^{* * *} P \leqslant 0.001$.

censused close in time (and also in space) to the cored trees and also similar in size to the cored trees, but not more efficient for species that were used for coring.
Table 2

Relationships between tape, ring and water growth in the nine cored trees. Effect sizes, goodness-of-fit (adj. $r$ squared values) and $p$-values are given.

\begin{tabular}{lcc}
\hline Linear regression & Adj. $R$ squared & $p$-Value \\
\hline Ring growth $=-0.06 \times$ water growth +0.24 & -0.002 & 0.36 \\
Ring growth $=0.21 \times$ tape growth +0.15 & 0.09 & 0.01 \\
Tape growth $=0.94 \times$ water growth +0.25 & 0.80 & $<0.001$ \\
\hline
\end{tabular}
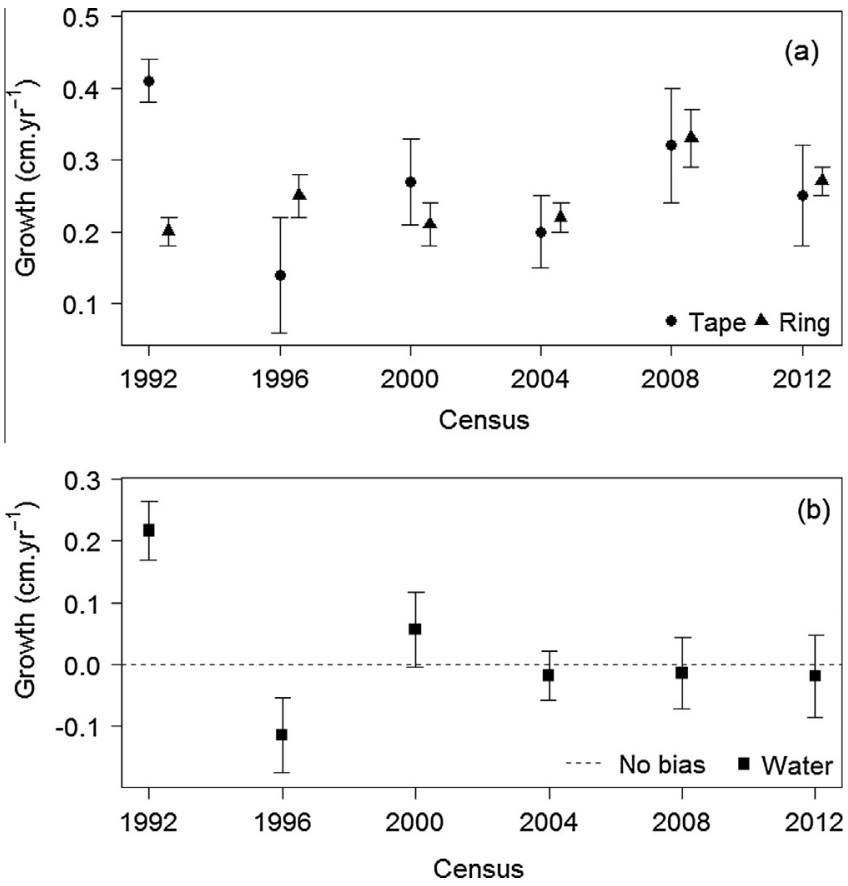

Fig. 3. (a) Ring versus tape and (b) water growth for the nine cored trees for each four yearly census interval. Mean with standard error bars are given.

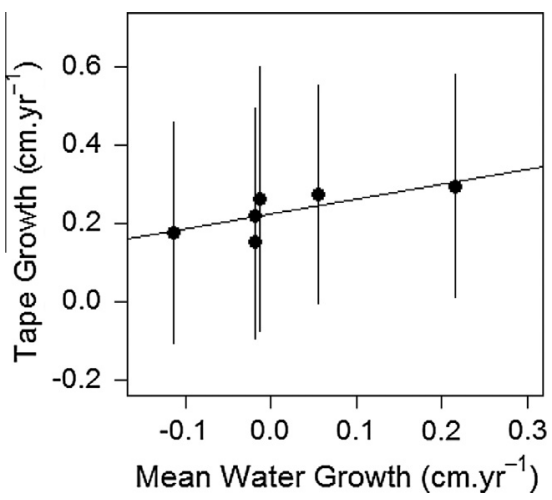

Fig. 4. Regression between census-wise tape growth at the "community-level" for 50 ha PSP in Mudumalai and water growth of the nine trees in the plot. Mean tape growth with standard deviation bars are given for each census-interval. Mean slope $=0.3800$ and $95 \%$ bootstrapped $\mathrm{CI}=[0.3524,0.4078], p$-value $<0.001$.

\section{Discussion}

While all census-intervals together for the cored nine trees, a large proportion of the variance in tape growth was attributable to water growth (Fig. 2d), census-interval wise analysis showed significant positive or negative bias only in the first two censuses, although variance among trees for a given census was large in all censuses (Fig. 3b). The fact that the mean of census-interval wise water growth in the cored trees showed significant linear relation 

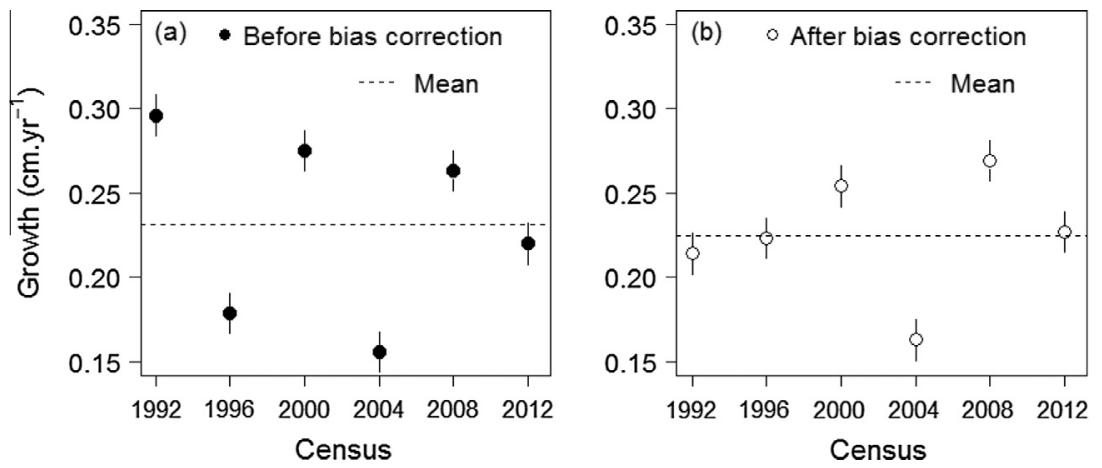

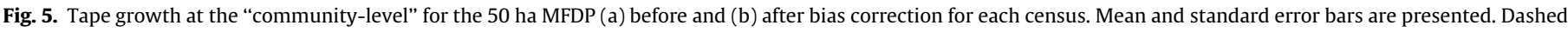
line represents mean growth rate across censuses.

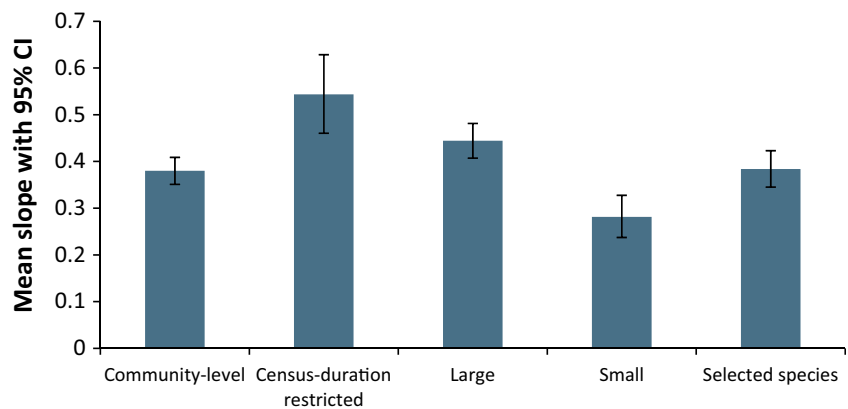

Fig. 6. Comparison between slopes of the linear relationship between census-wise water growth in the nine cored trees and each of the tree sets - "community-level", "census-duration restricted", "large" and "small", and "selected-species". Means and $95 \%$ bootstrapped confidence intervals of the slopes are given.

with census-interval wise tape growth at the "community-level" suggests that water growth measured in a few trees can be used as a proxy for estimating bias in tape growth at the scale of the tree community (Fig. 4).

The novelty of the proposed proxy for tree water growth is that it is directly estimated from trees, unlike the proxies suggested so far - based on rainfall or soil moisture - which are indirect (Baker et al., 2002; Sheil, 1997). While environmental data such as rainfall, PET, or soil moisture may or may not be available throughout the census period, tree ring data could be obtained retrospectively even several years after the survey is over, and would be useful for reinterpreting datasets where bias could not be avoided.

At the "community-level", detrending reduced the bias in growth estimates due to water-induced fluctuations, which reflected in the reduction in coefficient of variation in mean and median tape growth rates across census intervals. After bias correction mean tape growth rate for 2004-2008 census-interval emerged as the highest relative to all other censuses, while 2000-2004 mean tape growth rate emerged as the lowest. As 2004-2008 interval was the most resourceful in terms of rainfall (Fig. 1), and witnessed the highest water table levels in the last 50 years, as estimated by Ruiz et al. (2010) in a nearby forest, woody growth in this interval was expected to be the highest. On the other hand 2000-2004 census - interval included two of the strongest droughts in the last century, and thus woody growth during this interval was expected to be the lowest. These results are important indication that the proxy was able to reduce growth variations among periods, while highlighting exceptionally dry or wet periods.

Water flux related biases in growth estimates are also likely to pose problems in our understanding of general ecological theory. For example, in a pan-tropical assessment of allometric relationships between growth rates and tree diameter (MullerLandau et al., 2006), most plots showed consistent relationships across years, except for the driest forest plot - that happens to be the 50-ha MFDP. Here, large trees showed contrasting allometric relationship between consecutive census intervals, namely, 1992-1996 and 1996-2000. Nath et al. (2006) attributed the difference in growth rates in these censuses to difference in rainfall. We found that after correcting for bias this difference between large and small trees reduced substantially (Fig. 7), suggesting that to a large extent this anomalous behaviour may have arisen from over- or under-estimation of growth in the successive census intervals due to fluctuating water status of the trees.

This study tried to identify several sources of errors that cause bias in tape growth estimates, namely, measurement season, measurement time of the day, diameter and species. Although measurement errors are also possible, they are more likely to bias growth estimation when methods are inconsistent over time (Sheil, 1995), which was not the case here. Thus the observed biases are likely to have come from water-induced fluctuations. Diurnal water-induced fluctuations in the stem could potentially have contributed to observed biases (Sheil, 2003). However, this is likely to be marginal, because in a separate study (unpublished
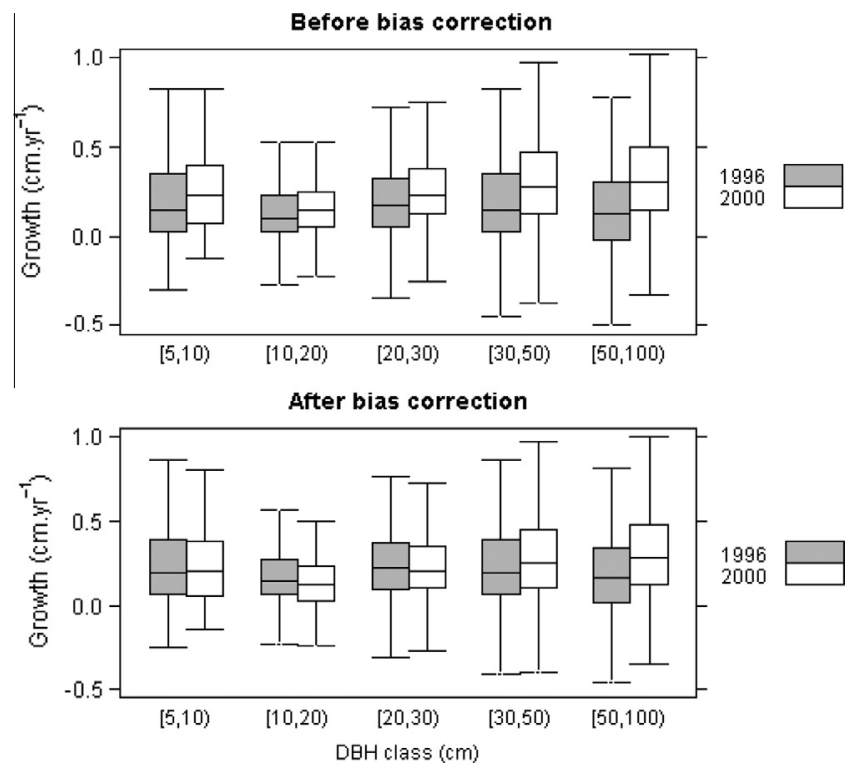

Fig. 7. Comparison of growth rates for census 1996 and 2000 according to size class before and after bias correction. The median (black line), interquartile range (IQR) (upper and lower limits of the boxes; 75 and 25 percentile), and variation extending from 5 to 95 percentile (whiskers) are given. Outliers are not shown. 
results), we observed that seasonal variations in stem diameter are about three times higher than diurnal variations, and diurnal fluctuations were observed mostly in the late afternoon, while the present survey was carried out between 9 am and $2 \mathrm{pm}$.

The efficacy of the proposed proxy is likely to increase by including trees representing the wide temporal range in census duration, or in the present case, various regions of the 50-ha MFDP, as indicated by the steeper slope of the relation between proxy and tape growth for the census-duration restricted set over the "community-level" trees set. The efficacy of the proxy is also likely to improve by including trees from various size classes and correcting their biases separately, as the proxy was most effective for trees that were of the same size class as that of the trees that were used for developing it. Including a larger variety of species may or may not improve the efficacy of the proxy, as the tape growth - proxy relationship did not improve when applied over only those species that were used for developing the proxy. The strength of the proposed proxy is not so much in it being representative of the whole community or explaining all the variance in water-induced fluctuations at the community level, as it is in its ability to capture the community-level potential water bias in each census. It might be surprising for community ecologists to define a proxy based on such a small set of trees as was done in this study, but proxies by definition are not meant to be completely representative; for example, a rainfall time series from a single rain-gauge does not represent all the spatial variation in water availability over a site but could still be effective in capturing the signal of temporal water availability.

Researchers have been seeking the best season of the year - wet or dry - in seasonal forests for annual or supra-annual diameter measurements to minimize water-induced biases, but have reached contrasting and debatable conclusions (Baker et al., 2002, Sheil, 2003). A separate study at the study site (unpublished results) indicated that biases- as measured from water growth remained and were not significantly different from each other irrespective of whether the wet or dry season was chosen for annual diameter measurement. This is perhaps because variation in water status in these trees remained high in either of the seasons, possibly mediated via variation in soil moisture, potential evapotranspiration. Also, the time in the year where variations in tree water status are minimal can vary from year to year, depending on weather conditions. Thus, whichever season tree growth is measured in, a correction would be necessary in order to estimate diameter growth without bias due to water-induced fluctuations. The proposed proxy, by trying to estimate the bias rather than avoiding it, is thus useful to end the conundrum of searching the season of least bias.

A large part of the variability remained unexplained by the proxy both at the "census-duration restricted" level as well as at the "community-level". This is understandable because change in water status is a function of a large number of factors - including species specific material properties of stem tissues, actual water availability as a function of precipitation in the recent past, soil properties, topography. Future work could include development of more effective proxies, possibly including several environmental variables and species-specific properties.

The results suggest that at least a part of the observed temporal variability in tape growth in this seasonally dry tropical forest arises from bias due to water-induced fluctuations. Especially in seasonally dry tropical forests, temporal growth variation gets almost exclusively attributed to temporal environmental variability and is explained as growth response to fluctuation in availability of resources, water in particular (Feeley et al., 2007; Nath et al., 2006; Toledo et al., 2011; Wagner et al., 2014). Correcting water growth induced biases in tree growth estimates would help in establishing actual woody growth-resource relationships.
Corrections applied to biases in the community/PSP level tree growth estimates in time could also substantially improve our understanding of carbon budgets of these forests and the effects of climatic and global changes on the temporal variation in biomass and carbon stocks and fluxes.

\section{Conclusions}

The results suggests that water growth measured in a few trees in each census - measured as the difference between diameter changes using tape and ring - can be effective in estimating bias in growth estimates due to water-induced fluctuations and measurement error at the community level. After bias correction the variability in mean growth rates across census-intervals decreased, while the effect of exceptionally dry or wet periods was retained, indicating that at least a part of the observed temporal variability in growth rates arose from reversible, water-induced fluctuations. This approach allows for reanalysis - and possible reinterpretation - of temporal trends in tree growth, above ground biomass change, or carbon fluxes in forests, and their relationships with resource availability in the context of climate change.

\section{Acknowledgements}

This study was supported by Ministry of Environment and Forest, Govt. of India. We thank Tamilnadu Forest Department for research permissions to work at Mudumalai. This work would not have been possible without the hard work of numerous tribal and local personnel in Mudumalai Wildilife Sanctuary, and CES staff over the past three decades. We thank Hemant Borgaonkar and Naveen Gandhi of IITM, Pune for helping with tree-ring width measurements. RCT was supported by a CSIR student fellowship. RS was a J.C. Bose National Fellow during the period of this study.

\section{Appendix A. Supplementary data}

Data used in this article are provided as supplementary information (SI_1_tree_ring_yearly_width_measurements.csv, SI_2_tree_bias_measurement_tape-ring_water_growth.csv, SI_3_ Mudumalai_FDP_tree_sets_growth_statistics_before bias_correction.xlsx). The Mudumalai FDP is part of the Centre for Tropical Forest Science, an international network of demographic tree plots. Tape diameter data of the Mudumalai FDP is archived in the CTFS repository (http://www.ctfs.si.edu/site/Mudumalai). Supplementary data associated with this article can be found, in the online version, at http://dx.doi.org/10.1016/j.foreco. 2014.10.007. These data include Google maps of the most important areas described in this article.

\section{References}

Baker, T.R., Affum-Baffoe, K., Burslem, D.F.R.P., Swaine, M.D., 2002. Phenological differences in tree water use and the timing of tropical forest inventories: conclusions from patterns of dry season diameter change. For. Ecol. Manage. 171, 261-274. http://dx.doi.org/10.1016/S0378-1127(01)00787-3.

Borchert, R., 1994a. Water status and development of tropical trees during seasonal drought. Trees 8, 115-125.

Borchert, R., 1994b. Soil and stem water storage determine phenology and distribution of tropical dry forest trees. Ecology 75, 1437-1449. http:// dx.doi.org/10.2307/1937467.

Champion, H.G., Seth, S.K., 1968. A Revised Survey of the Forests Types of India. Publication Division, Government of India, Delhi.

Chave, J., Andalo, C., Brown, S., Cairns, M.A., Chambers, J.Q., Eamus, D., Fölster, H., Fromard, F., Higuchi, N., Kira, T. Lescure, J.-P., Nelson, B.W., Ogawa, H., Puig, H. Riéra, B., Yamakura, T., 2005. Tree allometry and improved estimation of carbon stocks and balance in tropical forests. Oecologia 145, 87-99. http://dx.doi.org/ 10.1007/s00442-005-0100-X.

Chave, J., Réjou-Méchain, M., Búrquez, A., Chidumayo, E., Colgan, M.S., Delitti, W.B.C., Duque, A., Eid, T., Fearnside, P.M., Goodman, R.C., Henry, M., MartínezYrízar, A., Mugasha, W.A., Muller-Landau, H.C., Mencuccini, M., Nelson, B.W. 
Ngomanda, Nogueira, E.M., Ortiz-Malavassi, E., Pélissier, R., Ploton, P., Ryan, C.M., Saldarriaga, J.G., Vieilledent, G., 2004. Improved allometric models to estimate the aboveground biomass of tropical trees. Glob. Change Biol. 20, 3177-3190. http://dx.doi.org/10.1111/gcb.12629.

Clark, D.B., Kellner, J.R., 2012. Tropical forest biomass estimation and the fallacy of misplaced concreteness. J. Veg. Sci. 23, 1191-1196. http://dx.doi.org/10.1111/ j.1654-1103.2012.01471.x.

Condit, R., 1998. Tropical Forest Census Plots: Methods and Results from Barro Colorado Island, Panama and a Comparison with Other Plots. Springer-Verlag, Berlin.

Condit, R., Ashton, P.S., Manokaran, N., LaFrankie, J.V., Hubbell, S.P., Foster, R.B., 1999. Dynamics of the forest communities at Pasoh and Barro Colorado: comparing two 50-ha plots. Philos. Trans. R. Soc. Lond. B Biol. Sci. 354, 17391748. http://dx.doi.org/10.1098/rstb.1999.0517.

Cushman, K.C., Muller-Landau, H.C., Condit, R.S., Hubbell, S.P., 2014. Improving estimates of biomass change in buttressed trees using tree taper models. Methods Ecol. Evol. 5, 573-582. http://dx.doi.org/10.1111/2041-210X.12187.

Feeley, K.J., Joseph Wright, S., Nur Supardi, M.N., Kassim, A.R., Davies, S.J., 2007. Decelerating growth in tropical forest trees. Ecol. Lett. 10, 461-469. http:// dx.doi.org/10.1111/j.1461-0248.2007.01033.x.

Holbrook, N.M., Zwieniecki, M.A., 2011. Vascular Transport in Plants. Academic Press, New York, NY.

Karling, J.S., 1934. Dendrograph studies on Achras zapota in relation to the optimum conditions for tapping. Am. J. Bot. 21, 161-193. http://dx.doi.org/10.2307/ 2436370.

Klepper, B., Browning, V.D., Taylor, H.M., 1971. Stem diameter in relation to plant water status. Plant Physiol. 48, 683-685. http://dx.doi.org/10.1104/pp.48.6.683.

Kozlowski, T.T., 1971. Growth and development of trees: Cambial growth, root growth, and reproductive growth. Academic Press, New York, NY.

Kozlowski, T.T., Kramer, P.J., Pallardy, S.G., 1990. The Physiological Ecology of Woody Plants. Academic Press, New York, NY.

Kozlowski, T.T., Winget, C.H., 1964. Diurnal and seasonal variation in radii of tree stems. Ecology 45, 149-155. http://dx.doi.org/10.2307/1937115.

Maas, M., Burgos, A., 2011. Water dynamics at the ecosystem level in seasonally dry tropical forests. In: Dirzo, R., Young, H.S., Mooney, H.A., Ceballos, G. (Eds.), Seasonally Dry Tropical Forests - Ecology and Conservation. Island Press, Washington, D. C.

Malhi, Y., 2012. The productivity, metabolism and carbon cycle of tropical forest vegetation. J. Ecol. 100, 65-75. http://dx.doi.org/10.1111/j.13652745.2011.01916.x.

Markesteijn, L., Iraipi, J., Bongers, F., Poorter, L., 2010. Seasonal variation in soil and plant water potentials in a Bolivian tropical moist and dry forest. J. Trop. Ecol. 26, 497-508. http://dx.doi.org/10.1017/S0266467410000271.

Marthews, T.R., Metcalfe, D.J., Malhi, Y., Huaraca, H.W., Riutta, T., Ruiz-Jaen, M. Girardin, C.A.J., Butt, N., Cain, R., Oliveras, M.I., and colleagues from the RAINFOR and GEM networks, 2012. Measuring Tropical Forest Carbon Allocation and Cycling: A RAINFOR-GEM Field Manual for Intensive Census Plots (v2.2). (Manual).

Meinzer, F.C., Andrade, J.L., Goldstein, G., Holbrook, N.M., Cavelier, J., Wright, S.J., 1999. Partitioning of soil water among canopy trees in a seasonally dry tropical forest. Oecologia 121, 293-301. http://dx.doi.org/10.1007/s004420050931.

Muller-Landau, H.C., Condit, R.S., Chave, J., Thomas, S.C., Bohlman, S.A., Bunyavejchewin, S., Davies, S., Foster, R., Gunatilleke, S., Gunatilleke, N., Harms, K.E., Hart, T., Hubbell, S.P., Itoh, A., Kassim, A.R., LaFrankie, J.V., Lee, H.S., Losos, E. Makana, J.-R., Ohkubo, T., Sukumar, R., Sun, I.-F., Nur Supardi, M.N., Tan, S., Thompson, J., Valencia, R., Muñoz, G.V., Wills, C., Yamakura, T., Chuyong, G., Dattaraja, H.S., Esufali, S., Hall, P., Hernandez, C., Kenfack, D., Kiratiprayoon, S. Suresh, H.S., Thomas, D., Vallejo, M.I., Ashton, P., 2006. Testing metabolic ecology theory for allometric scaling of tree size, growth and mortality in tropical forests. Ecol. Lett. 9, 575-588. http://dx.doi.org/10.1111/j.1461-0248.2006.00904.x.

Muller-Landau, H.C., Detto, M., Chisholm, R.A., Hubbell, S.P., Condit, R., 2014. Detecting and projecting changes in forest biomass from plot data. In: Forests and Global Change, Ecological Reviews. Cambridge University Press, Cambridge.

Murali, K.S., Sukumar, R., 1993. Leaf flushing phenology and herbivory in a tropical dry deciduous forest, southern India. Oecologia 94, 114-119. http://dx.doi.org/ 10.1007/BF00317311.

Nath, C.D., Dattaraja, H.S., Suresh, H.S., Joshi, N.V., Sukumar, R., 2006. Patterns of tree growth in relation to environmental variability in the tropical dry deciduous forest at Mudumalai, southern India. J. Biosci. 31, 651-669. http://dx.doi.org/ 10.1007/BF02708418.

Pélissier, R., Pascal, J., 2000. Two-year tree growth patterns investigated from monthly girth records using dendrometer bands in a wet evergreen forest in India. J. Trop. Ecol. 16, 429-446. http://dx.doi.org/10.1017/ S0266467400001498.
Prasad, S.N., Hegde, M., 1986. Phenology and seasonality in the tropical deciduous forest of Bandipur, South India. Proc. Indian Acad. Sci. Plant Sci. 96, 121-133. http://dx.doi.org/10.1007/BF03053328.

Puri, G.S., 1960. Indian Forest Ecology: A Comprehensive Survey of Vegetation and Its Environment in the Indian Subcontinent. Oxford University Press, New Delhi.

R Core Team, 2013. R: A Language and Environment for Statistical Computing. R Foundation for Statistical Computing, Vienna, Australia.

Rao, K.S., Dave, Y.S., 1981. Seasonal variations in the cambial anatomy of Tectona grandis (Verbenaceae). Nord. J. Bot. 1, 535-542. http://dx.doi.org/10.1111/ j.1756-1051.1981.tb00719.x.

Ruiz, L., Varma, M.R.R., Kumar, M.S.M., Sekhar, M., Maréchal, J.-C., Descloitres, M., Riotte, J., Kumar, S., Kumar, C., Braun, J.-J., 2010. Water balance modelling in a tropical watershed under deciduous forest (Mule Hole, India): Regolith matric storage buffers the groundwater recharge process. J. Hydrol. 380, 460-472. http://dx.doi.org/10.1016/j.jhydrol.2009.11.020.

Scholz, F.C., Bucci, S.J., Goldstein, G., Meinzer, F.C., Franco, A.C., Miralles-Wilhelm, F., 2008. Temporal dynamics of stem expansion and contraction in savanna trees: withdrawal and recharge of stored water. Tree Physiol. 28, 469-480. http:// dx.doi.org/10.1093/treephys/28.3.469.

Sheil, D., 1995. A critique of permanent plot methods and analysis with examples from Budongo Forest, Uganda. For. Ecol. Manage. 77, 11-34. http://dx.doi.org/ 10.1016/0378-1127(95)03583-V.

Sheil, D., 1997. Long-term growth and rainfall in a Ugandan moist forest: seasonal rhythms and flexing stems. Commonw. For. Rev. 76, 121-127.

Sheil, D., 2003. Growth assessment in tropical trees: large daily diameter fluctuations and their concealment by dendrometer bands. Can. J. For. Res. 33, 2027-2035. http://dx.doi.org/10.1139/x03-121.

Sukumar, R., Dattaraja, H.S., Suresh, H.S., Radhakrishnan, J., Vasudeva, R., Nirmala, S. Joshi, N.V., 1992. Long term monitering of vegetation in a tropical deciduous forest in Mudumalai, southern India. Curr. Sci. 62, 608-616.

Sukumar, R., Suresh, H.S., Dattaraja, H.S., Joshi, N.V., 1998. Dynamics of a tropical deciduous forest: population changes (1988 through 1993) in a 50-ha plot at Mudumalai, southern India. In: Dallmeier, F., Comiskey, J.A. (Eds.), Forest Biodiversity Research, Monitoring and Modeling: Conceptual Background and Old World Case Studies. Parthenon Publishing, Paris, France, pp. 495-506.

Sukumar, R., Suresh, H.S., Dattaraja, H.S., John, R., Joshi, N.V., 2004. Mudumalai forest dynamics plot, India. In: Losos, E.C., Leigh, E.G. (Eds.), Tropical Forest Diversity and Dynamics: Findings from a Large-Scale Plot Network. University of Chicago Press, Chicago, pp. 551-563.

Suresh, H.S., Sukumar, R., 2009. Influence of climatic variability on tree phenology in the tropical dry forests of Mudumalai, southern India, In: Diloksumpun, S. Puangchit, L., (Eds.), Dry Forest Ecology and Conservation, vol. 5. Tropical Forestry Change in a Changing World. FORTROP II. International Conference. Presented at the Tropical Forestry Change in a Changing world. FORTROP II. International Conference, Bangkok, Thailand.

Suresh, H.S., Dattaraja, H.S., Sukumar, R., 2010. Relationship between annual rainfall and tree mortality in a tropical dry forest: results of a 19-year study at Mudumalai, southern India. For. Ecol. Manage. 259, 762-769. http://dx.doi.org/ 10.1016/j.foreco.2009.09.025.

Suresh, H.S., Dattaraja, H.S., Mondal, N., Sukumar, R., 2013. Seasonally dry tropical forests in southern India: an analysis of floristic composition, structure, and dynamics in Mudumalai Wildlife Sanctuary. In: McShea, W.J., Davies, S.J., Bhumakphan, N. (Eds.), The Ecology and Conservation of Seasonally Dry Forests in Asia. Smithsonian Institution Scholarly Press, Washington, D.C.

Talbot, J., Lewis, S.L., Lopez-Gonzalez, G., Brienen, R.J.W., Monteagudo, A., Baker, T.R. Feldpausch, T.R., Malhi, Y., Vanderwel, M., Araujo Murakami, A., Arroyo, L.P., Chao, K.-J., Erwin, T., van der Heijden, G., Keeling, H., Killeen, T., Neill, D., Núñez Vargas, P., Parada Gutierrez, G.A., Pitman, N., Quesada, C.A., Silveira, M., Stropp, J., Phillips, O.L., 2014. Methods to estimate aboveground wood productivity from long-term forest inventory plots. For. Ecol. Manage. 320, 30-38. http:// dx.doi.org/10.1016/j.foreco.2014.02.021.

Toledo, M., Poorter, L., Peña-Claros, M., Alarcón, A., Balcázar, J., Leaño, C., Licona, J.C. Llanque, O., Vroomans, V., Zuidema, P., Bongers, F., 2011. Climate is a stronger driver of tree and forest growth rates than soil and disturbance. J. Ecol. 99, 254264. http://dx.doi.org/10.1111/j.1365-2745.2010.01741.x.

Wagner, F., Rossi, V., Aubry-Kientz, M., Bonal, D., Dalitz, H., Gliniars, R., Stahl, C., Trabucco, A., Hérault, B., 2014. Pan-tropical analysis of climate effects on seasonal tree growth. PLoS ONE 9, e92337. http://dx.doi.org/10.1371/ journal.pone.0092337.

Worrall, J., 1966. A method of correcting dendrometer measures of tree diameter for variations induced by moisture stress change. For. Sci. 12, 427-429.

Zweifel, R., Häsler, R., 2001. Dynamics of water storage in mature subalpine Picea abies: temporal and spatial patterns of change in stem radius. Tree Physiol. 21, 561-569. http://dx.doi.org/10.1093/treephys/21.9.561. 